\title{
Hotel Brand and Food Quality in Malaysia
}

\author{
Tuan Ahmad Tuan Ismail, Rosmaliza Muhammad, \\ Norhayati Muhammad Yusoff, Mohd Shazali Md Shariff \\ Faculty of Hotel and Tourism Management, \\ Universiti Teknologi MARA (UiTM) Puncak Alam, 42300, Puncak Alam Selangor, Malaysia. \\ tuana436@salam.uitm.edu.my
}

\begin{abstract}
This study is to investigate the relationship between hotel brand and food quality using the Brand Identity Prism (BIP) model in the context of food service industry that has never been directly tested before. The attributes (physical, relationship and reflection) of BIP in food service industry which focusing on the food quality served at hotel restaurants are validated. A quantitative approach using questionnaire survey was conducted with a total of 129 hotel restaurants guests from four of five star rated hotels in Kuala Lumpur, Malaysia. The result indicated that there was a significant relationship between hotel brand identity and food quality.
\end{abstract}

Keywords: Hotel Brand Attributes; Food Quality; Brand Identity Prism Model; Hotel Restaurants

eISSN 2398-4279 @ 2018. The Authors. Published for AMER ABRA cE-Bs by e-International Publishing House, Ltd., UK. This is an open access article under the CC BY-NC-ND license (http://creativecommons.org/licenses/bync-nd/4.0/). Peer-review under responsibility of AMER (Association of Malaysian Environment-Behaviour Researchers), ABRA (Association of Behavioural Researchers on Asians) and cE-Bs (Centre for EnvironmentBehaviour Studies), Faculty of Architecture, Planning \& Surveying, Universiti Teknologi MARA, Malaysia.

DOI: https://doi.org/10.21834/ajqol.v3i10.98 


\subsection{Introduction}

There are potential economic benefits and consumer interests in hotel branding. Strong brands are therefore important to meet the challenges of highly volatile markets of today. To enhance their competitiveness, hotels need to create unique features that distinguish their offerings from those of their competitors (Doyle, 1994). An excellent food quality from hotel restaurants can be a strategic approach to their branding activities to ensure that they are better able to deal with fluctuating market forces. This method of merging between brand and food quality has little to know being conducted in the previous marketing research or specifically in the hotel and tourism sector.

Hotel industry must be cautious with their quality food offerings because it is an important attraction for both local and international customers. It is important to ensure that the brand's characteristics of food quality match consumers' expectations during their dining experience. By creating food quality and brand with distinctive features and own individuality will distinguish them from their competitors. Furthermore, food quality has been accepted as a fundamental element of the overall restaurant experience in the literature (Kivela, 1999; Raajpoot, 2002; Sulek, 2004).

In Malaysia, hotel industry operates in a business environment that is characterized by an intense competition and high uncertainty (Ong, 2004). Hence, branding activities, food and beverage offerings and subsequently maintaining food quality can be effective strategies to cope with the fluctuating market forces. Providing high food quality is important in the way that a satisfied customer will return and become a loyal customer.

While, strengthening the hotel brand means enhancing the customer's awareness and build a strong brand image in the mind of customers. However, hotel food quality and the significance of customer value including its relationship with hotel brand have seldom being studied empirically (Andersson \& Mossberg, 2004; Jensen \& Hansen, 2007). Spark et al. (2008) and Jensen and Hensen (2007) stated that future studies should empirically investigate the relationship between customer value and satisfaction and the related dimension of customer value after customers received food and beverage services.

The Brand Identity Prism (BIP) developed by Kapferer (1997) was proposed as a model for this study, as current marketing and brand management strategies in hotel industries were limited to advertising, word of mouth and service performance (Duncan \& Moriarty, 1998; Xu $\&$ Chan, 2010). This was achieved by adding value to the brand image, brand awareness, brand loyalty and the perceived quality to attract customers towards the hotel brand.

Despite the significant of food quality factor, a little study was found to focus on the significance of food quality as the core competency of a restaurant success (Namkung \& Jang, 2007). A common approach taken by most hotel restaurant operators to improve restaurant success is mainly focussed on delivering a pleasant atmospheric and outstanding service delivery, which is not enough in today's competitive environment (Baker, 1986; Campbell \& Smith, 1967; Hanefors \& Mossberg, 2003; MacLaurin, 2000). An integrated marketing strategy between hotel brand and food quality warrant further investigation to deal with the intense competition and high uncertainty environment for hotel businesses 


\subsection{Literature Review}

In the new branding era, brand identity is emphasized in brand building process (Kapferer, 1997). Recently much attention has been devoted to the business and management literature to the concepts of brand identity (D. A. Aaker \& Joachimsthaler, 2000) as cited by Konecnik (2008). To become, or to stay strong, brands must be true to their identity. The notion of brand image is both volatile and changing: its focus too much on brand appearance and not enough on brand essence (identity). The identity concepts crucial for three reasons: brands need to be durable, to send out coherent signs and to be realistic. It is thus a defence against the risks of an idealised, inconsistent or opportunistic brand image (Kapferer, 1997).

A brand is a distinctive identity that differentiates a relevant, enduring, and credible promise of value associated with a product, service or organization and indicates the source of that promise (Scott, Larry, \& Jonathan, 1999). A strong brand identity that is well understood and experienced by the customers helps in developing trust which, in turn, results in differentiating the brand from the competition. Its central concepts are brand identity, which must be defined and managed. A brand identity is a message sent out by the brand. Brand identity also represents what must stay and what is free to change (Kapferer, 1997).

Kapferer (1997) has developed a model called "the Brand Identity Prism" (BIP) which consist of six facets that reflects the different aspects of brand identity. The model is very extensive, and the six facets which are; physique, personality, culture, reflection, relationship and self-image. According to Kapferer (1992), the prism aims to distinguish one brand from another brand by examining and exploring each facet. In this study, three-facets was utilized namely physical, relationship and reflection to examine their influence towards food quality factor.

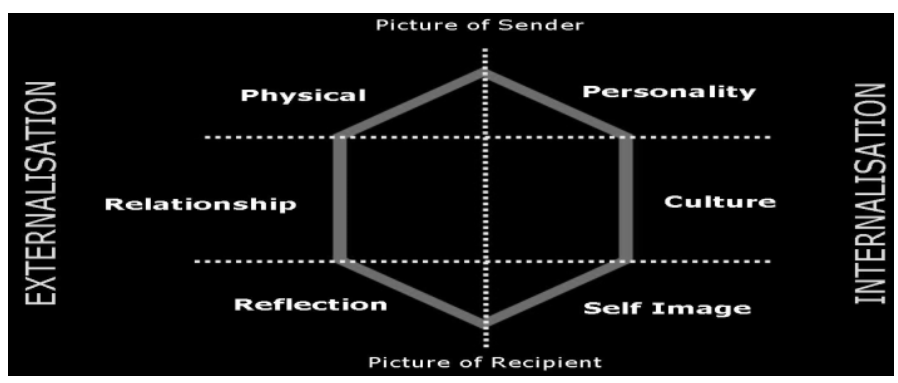

While brand attributes associated with tangibles goods has received a great deal of attention in the literature, a basic understanding of the nature of brand for service has yet to emerge (Rüçhan \& Huseyin, 2007). There is a gap in the literature as to what is means by hotel brand, how it should be view and operationalized (Bailey R., 2006; Rüçhan \& Huseyin, 2007), there is still lack of empirical data in hotel brand (Cobb-Walgren., 1995; Kim \& Kim, 2005; Prasad, 2000). It is proposed that this confusion may affect the abilities of hotel companies to manage their brands effectively, as well as limit the development of a theory of a hotel brand (Bailey R., 2006).

Moreover, previous researchers have investigated the restaurants in relation to customer satisfaction, emotion, and loyalty (Andersson \& Mossberg, 2004; Arora, 2006; Hanefors \& 
Mossberg, 2003; Lockyer T, 2005), service quality in restaurants (Jaksa, John, \& Robert, 1999; Kivela \& Crotts, 2006; Mohsin, 2005; Myung, 2008; Namkung \& Jang, 2007; Oh, 2000; Park, 2004; Ryu \& Jang, 2006; Van Djick \& Kirk., 2007; Yuksel \& Yuksel, 2002).

Furthermore, investigations about the important of food quality in the hotel restaurant are limited (Kivela \& Crotts, 2006).Current studies concerning restaurants (Andersson \& Mossberg, 2004; Arora, 2006; Hanefors \& Mossberg, 2003; Lockyer T, 2005; Oh, 2000; Yuksel \& Yuksel, 2002) investigated overall service quality and satisfaction rather than food quality and largely focused on independent restaurants and not in the hotel restaurants sector.

\subsection{Methodology}

This study employs quantitative approach. A self-administered questionnaire was applied which enables researchers to distribute numerous questionnaires to many respondents at different places simultaneously. This method was deemed suitable for collecting data from various hotels at different locations in a relatively short period. Ability to obtain first-hand descriptions of the specified domain of the study (Hasting \& Perry, 2000) was also considered for this study to explore the hotel BIP that conveys meaning to customers. Data were collected during the month of May and June 2014 in the city of Kuala Lumpur. The questionnaires used closed question with numerical Likert scales ranging from 1 (strongly disagree) to 7 (strongly agree) to give more refined options to the respondents. The data collection session lasted for seven weeks. A total of 129 hotel restaurant guests had responded and participated in the survey. The data obtained were analyzed by descriptive and inferential statistic using Statistical Package for Social Science Version 17.0 (SPSS).

\subsection{Findings and Discussions}

The respondents consisted of 73 male $(51.0 \%)$ and 56 female (49.0\%). $34.2 \%$ were $25-34$ followed by $29.3 \%$ of $35-44,22.6 \%$ of $45-54,10.4 \%$ of $18-24$ and $3.5 \%$ of 55 and over. Malay group led with $69.1 \%, 14.7 \%$ - Chinese, $9.1 \%$ of Indian ethnic and $7.1 \%$ of others ethnic. $46.7 \%$ had a bachelor degree, $27.8 \%$ - diploma, $12.0 \%$ - master degree, $11.2 \%$ - high school and $2.3 \%$ were $\mathrm{PhD}$ holder. In occupation, $41.1 \%$ were government officer, followed by $30.7 \%$ - professional, $9.3 \%$ of others occupation, $7.1 \%$ - business owner, $6.8 \%$ - student, $2.5 \%$ retired and $2.5 \%$ is a housewife. $32.2 \%$ were occasionally dined at a hotel restaurant in a year, followed by $23.9 \%$ rare, $21.0 \%$ - very rare, $14.1 \%$ - often and $8.9 \%$ - very often. $36.9 \%$ of the respondents said that will bring family, $32.8 \%$ - friends, $16.4 \%$ - business associates, $10.8 \%$ - spouse and $3.1 \%$ would prefer to come alone. $36.1 \%$ dine at the restaurants because of special occasion, followed by $26.6 \%$ - business meeting, $25.3 \%$ family dinner, $6.4 \%$ because of curiosity and $5.6 \%$ of other reasons. 74 respondents (55.8) stayed at the hotel, while 55 respondents (44.2\%) are not staying in the hotel. 
Table 1: Profile of Respondents

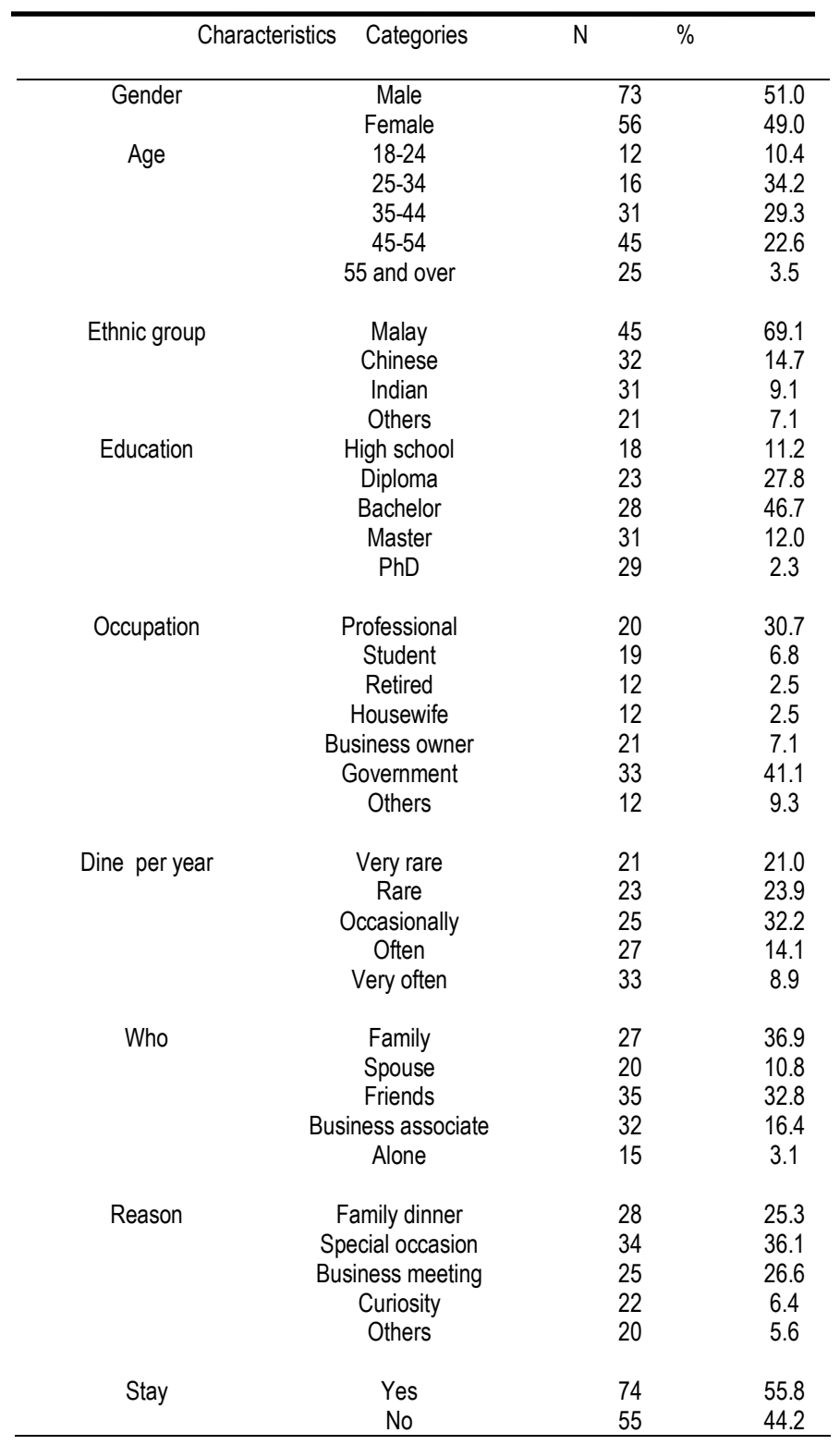

The analysis was made to identify the contribution direction of independent variable(s) that has an influence on food quality. The result is shown below. 
Table 2: Regression results of Hotel Brand Identity Variables on Food Quality ( $\mathrm{N}=482)$

\begin{tabular}{|l|l|l|l|l|l|}
\hline Variables & Beta & $\begin{array}{l}\text { Std } \\
\text { error }\end{array}$ & $\begin{array}{l}\text { Std. } \\
\text { Beta }\end{array}$ & $\mathrm{t}$ & Sig. \\
\hline Physical & .056 & .033 & .099 & 1.712 & .088 \\
Relationship & .290 & .042 & .389 & 6.946 & .000 \\
Reflection & -.098 & .043 & -.128 & -2.277 & .023 \\
& & & & & \\
\hline
\end{tabular}

${ }^{*}$ Sig. at $a=.05$ level

There is a significantly positive relationship between physical and food quality because the calculated value of $t$ is $1.712, p=.088, p>a=0.05$; It is concluded that hotel physical facet has a positive relationship with food quality. There is a significantly positive contribution to the relationship and food quality because the calculated value of $t$ is $6.946, p=.000$; therefore, there is significantly positive contribution between relationship and food quality at the $a=0.05$ level.

There is no significant relationship between Reflection and food quality because the calculated value of $t$ is $-2.277, p=.023$. This means that there is no significant relationship between reflection and food quality.

According to the Table 2 above, based on the value of standardized beta, relationship (.389) has the highest relationship with food quality, followed by Physical (.099) and, reflection (.128) respectively. Overall, it is concluded that hotel brand has a relationship with food quality.

Table 3: Cumulative relationship of Hotel Brand and Food Quality

\begin{tabular}{|l|l|l|l|l|l|}
\hline $\mathrm{R}$ & R Square & $\begin{array}{l}\text { Adjusted R } \\
\text { Square }\end{array}$ & $\begin{array}{l}\text { Std. Error of } \\
\text { the Estimate }\end{array}$ & $\mathrm{F}$ & Sig. \\
\hline .718 & .516 & .510 & .708 & 84.389 & .000 \\
\hline
\end{tabular}

a. Predictors: (Constant), Physical, Relationship, Reflection.

b. Dependent Variable: Food Quality

Table 3 shows that the multiple regression coefficients $(R)$ of at least one independent variable of Hotel Brand Identity, which have effect on Food Quality, were .718, and the Rsquare is .516. The results suggest that 51 percent of the variance (R Square) in food quality has been significantly explained by the group of three Hotel Brand Identity independent 
variables, as shown by the $F$ value of 130.315 , significant at the $\alpha=0.05$. This means that there is at least one independent variable is significantly contributed to food quality. There is both positive or negative relationship between independent variables (Hotel Brand Identity) and food quality.

\subsection{Conclusion}

Overall, food quality found to significantly influence the Hotel Brand Identity in the context of this study. The finding provides valuable insight for the hotel brand managers in integrating brand attributes with food quality factor. Therefore, it can provide the hotel in Malaysia with the possible solution to increase profitability and enhance hotel brand image which characterized by an intense competition and high uncertainty of hotel business environment.

\section{Acknowledgement}

This paper has received the support of Faculty of Hotel and Tourism, Universiti Teknologi Mara (UiTM) Puncak Alam, Malaysia.

\section{References}

Aaker. (2000). Brand Leadership. New York: Free Press.

Andersson \& Mossberg. (2004). The dining experience: do restaurants satisfy customer needs? Food Service Technology, 4, 171-177.

Arora, R. S., J. (2006). Cognitive and affective service marketing strategies for fine dining restaurant managers. Journal of Small Business Strategies, 17(1), 51.

Bailey R., B. S. (2006). An exploration of the meaning of hotel brand equity. The Service Industry Journal, 26(1), 1538.

Balaji, C. K., \& Michael, D. H. (2001). Brand equity: Is it more important in services? The Journal of Services Marketing, 15(4/5), 328.

Bhimrao, M. G. (2008). Building brand identity in competitive markets: a conceptual model. The Journal of Product and Brand Management, 17(1), 4.

Cai L.A., H. J. S. (2004). Making hotel brands work in a competitive environment Journal of Vacation Marketing, 10(3), 197-206.

Caldwell, C., \& Hibbert, S. A (2002). The influence of music tempo and musical preference on restaurant patron's behavior. Psychology and Marketing, 19(11), 895-917.

Dubé, L., Renaghan, L. M., \& Miller, J. M. (1994). Measuring customer satisfaction for strategic management. The Cornell Hotel and Restaurant Administration Quarterly, 35(1), 39-47. doi:10.1016/0010-8804(94)90063-9

Forgacs G. (2006). Brand asset and balancing act in the hotel industry. Hospitality Industry Trend, 5, August 
Hanefors \& Mossberg. (2003). Searching for the extraordinary meal experience. Journal of Business and Management, 9(3), 249.

Heskett, J. L., Jones, T. O., Loveman, G. W., Sasser, W. E., Jr., \& Schlesinger, L. A. (1994). Putting the serviceprofit chain to work. Harvard Business Review, 72(2), 164.

Jensen, Ø., \& Hansen, K. V. (2007). Consumer values among restaurant customers. International Journal of Hospitality Management, 26(3), 603-622. doi:10.1016/j.jphm.2006.05.004

Jiang, W., Dev, C., \& Rao, V. (2002). Brand extension and customer loyalty: Evidence from the lodging industry. Cornell Hotel and Restaurant Administration Quarterly, 43(4), 5-16.

Kapferer, J.-N. (1997). Strategic brand management: creating and sustaining brand equity long term (2nd ed.). London ; Dover, N.H.: Kogan Page.

Keller, K. L. (2003). Strategic brand management: building, measuring, and managing brand equity (2nd ed.). Upper Saddle River, N.J.: Prentice Hall.

Kim, H.-b., \& Kim, W. G. (2005). The relationship between brand equity and firms' performance in luxury hotels and chain restaurants. Tourism Management, 26(4), 549-560. doi:10.1016/j.tourman.2004.03.010

Kivela \& Crotts. (2006). Tourism and gastronomy: Gastronomy's influence on how tourists experience a destination. Journal of Hospitality \& Tourism Research, 30(3), 354-377.

Konecnik, M., \& Go, F. (2008). Tourism destination brand identity: The case of Slovenia. Journal of Brand Management, 15(3), 177.

Lockyer T. (2005). The Dining Experience: Critical areas of guest satisfaction. Journal of Hospitality \& Tourism Management, 12(2), 50.

Mikela J., C. d. o. t. m. I. H. L. M. E., Dimension of the meal: The science, culture, business and art of eating. Aspen, MD: Aspen Publishers, 7-18. (2000). Cultural definitions of the meal: Aspen, MD: Aspen Publishers.

Mohsin, M. C. (2005). Expectation of the service experience offered by restaurants and cafe's in Hamilton, New Zealand. Journal of Hospitality \& Tourism Management, 12(1), 108.

Namkung, Y., \& Jang, S. (2007). Does food quality really matter in restaurants? Its impact on customer satisfaction and behavioral intentions. Journal of Hospitality \& Tourism Research, 31, 387.

Oh. (2000). Diner's perception of quality, value, and satisfaction. Cornell Hotel and Restaurants Quarterly, 41(3), 58 .

Olsen M.D., C. Y., Graf N., Lee K., \& Madanoglu M. . (2005). Branding: myth and reality in the hotel industry. Journal of Retail \& Leisure Property 4(2), 146-162.

Park. (2004). Efficient or enjoyable? Consumer values of eating-out and fast food restaurant consumption in Korea. International Journal of Hospitality Management, 23, 87-94.

Prasad, K., \& Dev, C.S. (2000). Managing hotel brand equity: A customer- centric framework for assessing performance. Cornell Hotel and Restaurant Administration Quarterly, 41(3), 22-31.

Riley, M. (2005). Food and beverage management: A review of change. International Journal of Contemporary $\begin{array}{lllll}\text { Hospitality } \quad \text { Management, } & 17(1), & 88 . & \text { Retrieved }\end{array}$ http://ezproxy.lincoln.ac.nz/login?url=http://proquest.umi.com/pqdweb?did=815876681\&Fmt=7\&clientld=18963\&R 
Rüçhan, K., \& Huseyin, A. (2007). Customer based brand equity: evidence from the hotel industry. Managing Service Quality, 17(1), $\quad 92 . \quad$ Retrieved from http://ezproxy.lincoln.ac.nz/login?url=http://proquest.umi.com/pqdweb?did=1204214481\&Fmt=7\&clientld=18963\& $\mathrm{RQT}=309 \& \mathrm{VName}=\mathrm{PQD}$

Ryu \& Jang. (2006). Intention to experience local cuisine in a travel destination: The modified Theory of Reasoned Action. Journal of hospitality \& Tourism Research, 30(4), 507-516.

Stevens, P., Knutson, B., \& Patton, M. (1995). . (1995). DINESERV: A tool for measuring service quality in restaurants. Cornell Hotel and Restaurant Administration Quarterly,, 36(2), 56-60.

Van Djick \& Kirk. (2007). Being somebody else: Emotional labour and emotional disonnance in the context of the service experience at a heritage tourism site. Journal of Hospitality \& Tourism Management, 14(2), 157-169.

Wu, C. H.-J., \& Liang, R.-D. (2009). Effect of experiential value on customer satisfaction with service encounters in luxury-hotel restaurants. International Journal of Hospitality Management, 28(4), 586-593. doi:10.1016/j.jjhm.2009.03.008

Yuksel \& Yuksel. (2002). Measurement of tourist satisfaction with restaurant service: a segment-based approach. Journal of Vacation Marketing, 9(1), 52. 